\title{
MANAJEMEN KEPEMIMPINAN DALAM MENINGKATKAN ETOS KERJA ISLAMI KARYAWAN PT. DISTHI MUTIARA SUCI BANYUWANGI PASCA PAILID
}

\author{
Diana Mutmainnah ${ }^{1}$, Syarifuddin ${ }^{2}$ \\ Mutmainnah30@gmail.com ${ }^{\mathbf{1}}$, syarifuddinahm@gmail.com ${ }^{2}$ \\ Universitas Ibrahimy Situbondo
}

\begin{abstract}
ABSTRAKC
Work ethic is becoming increasingly important at this time, due to lack of employee discipline which causes a decreased work ethic, especially after the bankruptcy at PT. Disti Mutiara Suci thus requires a leader to foster employee work ethics again, in this case it is necessary to implement leadership management in improving employee Islamic work ethics and also know what are the inhibiting and supporting factors of employee Islamic work ethics. The results of this study indicate that leadership management in improving the work ethic of post-bankrupt Islamic employees is a leader who does not restrain his employees so that it is easy to foster a post-bankrupt employee work ethic. And leaders better understand karwanan by not leaving the rules that apply in a company. The supporting factors are the applied promotion, trainings, good communication applied by the leader to subordinates, having trust in the subordinates. Whereas the obstacle factor in this case is the lack of smooth access to enter the work location so that the leadership is difficult to directly monitor, lack of professional work of employees and lack of employee loyalty to the company.
\end{abstract}

\section{PENDAHULUAN}

Al-Quran telah memberikan gambaran tentang konsep Kepemimpinan. Pada dasarnya konsep dasar yang digarisbawahi oleh al-Qur'an adalah untuk mengelola hubungan sesama manusia dan alam lingkungannya. Oleh karena itu tipe leadership dalam Islam tidak hanya mengarah kepada ukhrawi semata melainkan segala sesuatu yang mencakup urusan duniawi dan ukhrawi.

Kepemimpinan merupakan proses mempengaruhi orang lain agar termotivasi dan tergerak dalam mencapai tujuan organisasi. Kepemimpinan merupakan kuasa seseorang dalam mempengaruhi, mendorong, membimbing, mengarahkan dan menggerakkan orang lain agar mau bekerjasama dengan penuh semangat dan kepercayaan dalam mencapai tujuan bersama (Syafi'i Antonio, 2007). Seorang pemimpin memainkan peranan yang sangat penting, tidak hanya secara internal bagi organisasi yang bersangkutan, tetapi juga 
dalam menghadapi berbagai pihak di luar ogranisasi yang semuanya dimaksudkan untuk meningkatkan kemampuan organisasi untuk mencapai tujuan (Nana Herdiana Abdurrahman, 2013).

Efektifitas dan efesiensi merupakan dua hal yang terpenting dalam menilai suatu kinerja yang dapat tercapai melalui disiplin kerja karyawan. Disiplin dapat dibina melalui pelatihan-pelatihan yang akan memberikan pengaruh positif terhadap kinerja karyawan. Faktor lain yang dianggap mempengaruhi kinerja adalah etos kerja yang tinggi akan mendorong orang untuk mencerminkan rasio dalam perilakunya dan menguasai dirinya, sehingga menunjukkan "Self discipline". Jadi disini etos kerja yang dianggap mempengaruhi munculnya suasana disiplin. Tanpa mempunyai semangat yang tinggi, amat sulit tercipta sikap disiplin, karena semangat yang tinggi merupakan kondisi pendahuluan yang amat penting untuk landasan lahirnya disiplin pegawai (Marsyaf Rinaldi, Oktober 2016).

Kerja keras atau dengan kata lain yang dinamakan etos kerja. Etos bukan sekedar bergerak atau bekerja, melainkan kepribadian yang bermuatan moral dan menjadikan landasan moralnya tersebut, sebagai cara dirinya mengisi dan menggapai makna hidup yang diridhai-Nya. Menggapai kebahagiaan didunia dan diakhirat, sehingga etos kerja bekaitan dan bersenyawa dengan semangat, kejujuran, dan kepiawaian dalam bidanganya (Toto Tasmara, 2002).

Ditengah kepungan zaman yang serba modern ini, seakan nilai etika semakin luntur, bahkan boleh dibilang mulai hilang karena kecenderungan masyarakat untuk berlaku bebas seakan sudah mewabah disetiap lini kehidupan. Karena sesungguhnya etos berkaitan dengan nilai kejiwaan seseorang hendaknya setiap pribadi muslim harus mengisinya dengan kebiasaan yang positif dan mampu menunjukkan kepribadiaanya sebagai seorang muslim dalam bentuk hasil kerja serta sikap dan prilaku yang menuju atau mengarah kepada hasil yang lebih sempurna (Nanda Hidayan dkk, 2017).

Indonesia merupakan negara yang kaya akan hasil alamnya karena itu indonesia dikatakan sebagai negara agraris dan negara maritim. Negara Agraris merupakan negara yang memiliki banyak hutan dan perkebunan, yang sebagian besar masyarakatnya bekerja sebagai petani sehingga berpotensi untuk melakukan kegiatan ekonomi. Sedangkan Indonesia juga tidak kalah menakjubkan, Indonesia juga merupakan negara maritim yang memiliki luas laut lebih besar dibandingkan dengan daratan. 
Laut Jawa Timur merupakan salah satu dari sekian laut yang memiliki laut yang kurang baik atau ekosistem terumbu karang yang kondisinya kurang baik utamanya di Taman Nasional Alas Purwo, Banyubiru, kecamatan Muncar, Kabupaten Banyuwangi, Jawa Timur, dikarenakan nelayan yang berada di daerah setempat melakukan penangkapan ikan dengan cara penggunaan bahan peledak, potasium dan lainnya sehingga berdampak terhadap kehidupan bawah laut utamanya ekosistem terumbu karang yang juga merupakan cikal bakal pertumbuhan biota laut. Namun disini perusahaan hadir bukan semata-mata untuk mencari keuntungan tetapi bagaimana agar ekosistem laut itu terjaga karena budidaya kerang mutiara ini merupakan budaya yang ramah lingkungan. Dengan tidak merugian masyarakat yang berada di daerah setempat dengan memberikan konpensasi yang setimpal karena mempersempit wilayah tangkap mereka.

PT. Disthi Mutiara Suci ini berdiri sejak tahun 2007 dan bekerja sama dengan investor asing dan pada tahun 2017 perusahaan tersebut mengalami Pailit karena beberapa faktor diantaranya faktor kerja sama yang sudah habis dengan investor asing (PMA) sehingga PT. Disthi Mutiara Suci harus mencari investor lain agar bisa bekerja sama membangun kembali perusahaan tersebut. Namun tahap pencarian investor ini membutuhkan waktu kurang lebih setengah tahun, sehingga mengakibatkan tidak adanya pemasukan pada PT. Disthi Mutiara Suci. Pimpinan perusahaan tersebut dengan terpaksa harus mengurangi karyawan yang ada karena kurangnya dana untuk membayar gaji karyawan, kecuali mereka yang tetap ingin bekerja dengan suka rela dengan gaji yang kecil. Dengan alasan telah bekerja cukup lama sehingga timbul rasa kekeluargaan diantara pimpinan dan karyawan. Karyawan yang bertahan sampai dengan pulihnya perusahaan adalah sejumlah 8 orang dengan tidak memberikan hal selayaknya seperti gaji dan jamiman kesehatan. Sedangkan pada tahun 2017 akhir perusahaan mendapatkan investor lain guna membangun kembali perusahaan, dengan bermodal karyawan yang sedikit tidak semerta menurunkan tekat untuk bangkit kembali, sehingga setelah mendapatkan investor lain PT. Disthi Mutiara Suci merekrut karyawan guna menghidupkan kegiatan bisnis seperti sediakala.

Melihat keadaan tersebut, peneliti berpendapat bahwa kepemimpinan yang ada di PT. Disthi Mutiara Suci merupakan pemimpin yang mempunyai tekat yang kuat untuk membangun kembali perusahaannya, karena membangun suatu perusahaan yang sempat Pailit sangatlah tidak mudah. Dengan dukungan dan semangat para pegawai yang 
minoritas direkrut kembali pasca PHK (Pemutusan Hubungan Kerja), sehingga PT. Disthi Mutiara Suci bisa berdiri kembali. Sehubungan dengan apa yang telah peneliti paparkan maka penelitian ini fokus pada dua persoalan yaitu: Bagaimana penerapan manajemen kepemimpinan dalam meningkatkan etos kerja islami karyawan pasca Pailit di PT. Disthi Mutiara Suci? Apa saja faktor penghambat dan pendukung dalam meningkatkan etos kerja Islami karyawan pasca Pailit PT. Disthi Mutiara Suci?

\section{KAJIAN TEORI}

\section{Manajemen Kepemimpinan}

Manajemen adalah seni memperoleh hasil melalui orang lain atau manajemen sebagai proses menetapkan dan memperoleh tujuan (sasaran) melalui lima fungsi dasar dengan menggunakan sumber daya yaitu manusia dan uang (M. Manullang, 2008). Menurut Sadili, ada yang menyebutkan manajemen sebagai ilmu dan ada pula yang berpendapat manajemen sebagai seni. Manajemen sebagai ilmu adalah suatu kumpulan pengetahuan yang logis dan sistematis. Manajemen sebagai seni adalah suatu kreativitas pribadi yang disertai suatu keterampilan (Sadili Samsudin, 2006).

Banyak para ahli yang berbeda pendapat tentang manajemen, akan tetapi diantara pendapat mereka mempunyai persamaan arah dan tujuan jika dilihat dari fungsi-fungsi manajemen sebagaimana pendapat berikut: Henry Fayol Berpendapat bahwa fungsi mnajemen adalah: Planning, organizing, commanding, Leanding, Controling yaitu perencanaa, pengorganisasian, pemberian perintah, pengordinasian, dan pengendalian. Louis Allen Berkomentar bahwa fungsi manajemen adalah Planning, Organizing, Leading, Controlling (Soetopo Hendyat, 1992). Stephen P. Robbin Berpendapat sama dengan Allen yaitu : Planning, Organizing, Leading, Controlling ( Perencanaan, Pengorganisasian, Pengarahan, Pengawasan).

Dari tiga pendapat tersebut diatas, kenyataan para ahli lebih cenderung kepada pendapat Allen sebagai fungsi pokok manejemen, yaitu Planning, Organizing, Leading, dan Controlling (Perencanaan, Pengorganisasian, Pengarahan, dan Pengawasan). Jadi manajemen pada dasarnya adalah upaya mengatur segala sesuatu (sumber daya) untuk mencapai tujuan organisasi. Dalam kegiatan mengatur ini kemudian timbul beberapa masalah. Siapa yang mengatur, mengapa harus diatur, dan apa tujuan dari pengaturan tersebut. Dari pernyataan tersebut maka diperlukan kegiatan mempelajari, mendalami dan 
mempraktikkan konsep manajemen secara baik sehingga tujuan organisasi dapat dicapai dengan baik.

Karena sifat pengaturan melekat pada manajemen, maka banyak orang yang mengartikan manajemen sebagai tata laksana atau ketatalaksanaan, yaitu suatu kegiatan mengatur, membimbing dan memimpin orang-orang menjadi bawahan untuk mecapai tujuan yang telah ditetepkan. Dari uraian tersebut tampak bahwa dalam manajemen terdapat dua hal penting, yaitu: Jabatan, yaitu kedudukan-kedudukan yang disediakan bagi orang-orang yang memenuhi syarat da keahlian dalam jabatan tersebut. Job, yaitu pekerjaan merencanakan, mengatur, mengarahkan, melaksanakan, dan mengawasi atau megendalikan jalannya kegiatan dalam pencapaian tujuan tertentu.

\section{Kepemimpinan}

Definisi tentang kepemimpinan bervariasi sebanyak orang yang mencoba mendefinisikan konsep kepemiminan. Definisi kepemimpinan secara luas meliputi proses memengaruhi dalam menentukan tujuan orgamisasi, memotivasi perilaku pengikut untuk mencai tujuan, memengaruhi untuk memperbaiki kelompok dan budayanya (Veitzal Rivai Zainal dkk, 2017). Kepemimpinan adalah kemampuan meyakinkan dan menggerakkan orang lain agar mau bekerja sama di bawah kepemimpinannya sebagai suatu tim untuk mencapai suatu tujuan tertentu (Soetopo Hendyat, 1992). Seperti manajemen, kepemimpinan (leadership) telah didefinisikan dengan berbagai cara yang berbeda oleh berbagai orang yang berbeda pula. Menurut Stoner, kepemimpinan menejerial dapat didefinisikan sebagai suatu proses pengarahan dan pemberian pengaruh pada kegiatan-kegiatan dari sekelompok anggota yang saling berhubungan tugasnya (T. Hani Handoko, 2015).

Pemimpin dan kepemimpinan adalah ibarat sekeping mata uang logam yang tidak dapat dipisahkan, dalam artian bisa dikaji secara terpisah namun harus dilihat sebagai satu kesatuan. Seorang pemimpin harus memiliki jiwa kepemimpinan dan jiwa kepemimpinan yang dimiliki dari seseorang pemimpin adalah tidak bisa diperoleh dengan cepat dan segera, namun sebuah proses yang terbentuk dari waktu ke waktu hingga akhirnya mengkristal dalam sebuah karakteristik (Irhami Fahmi, 2018).

\section{Tipe kepemimpinan}

Beberapa tipe kepemimpinan yang dikenal adalah: Pertama, Tipe Kharismatis. Pemimpin kharismatis merupakan kekuatan energi, daya tarik yang luar biasa yang akan 
diikuti oleh para pengikutnya. Pemimpin ini mempunyai keistimewaan tertentu misalnya mempunyai kekuatan gaib, manusia super berani dan sebagainya. Kedua, Tipe Paternalistis dan Maternalistis. Pemimpin paternalistis bersifat melindungi bawahan, sebagai seorang bapak atau sebagai seorang ibu yang penuh kasih sayang. Pemimpin tipe ini kurang memberikan kesempatan kepada karyawannya untuk berinisiatif dan mengambil keputusan. Ketiga, Tipe Militeristis. Pemimpin militeristis ini menggunakan sistem perintah, sistem komandan dari atasan ke bawahan sifatnya keras sangat otoriter, menghendaki bawahannya melakukan yang diinginkan. Keempat, Tipe Otokratis. Tipe otokratis ini berasarkan kepada kekuasan dan paksaan yang mutlak harus dipatuhi. Pemimpinnya selalu berperan sebagai pemain tunggal, dia menjadi raja. Setiap perintah ditetapkan tanpa konsultasi dan kekuasaan sangat absolute. Kelima, Tipe Laissez Faire. Tipe ini membiarkan bawahan berbuat semaunya sendiri semua pekerjan dan tanggung jawab dilakukan oleh bawahan. Pemimpinnya hanya merupakan simbol yang tidak memiliki keterampilan. Jabatan pemimpin diperoleh dengan jalan yang tiak benar, mungkin melalui sistem nepotisme. Pemimpin ini tidak berwibawa, tidak mampu mengawasi karyawan tidak mampu mengkoordinasi, suasana kerja tidak kooperaktif. Keenam, Tipe Populistis. Tipe populistis ini mampu menjadi pemimpin rakyat. Dia berpegang pada nilai-nilai masyarakat tradisional. Ketujuh, Tipe Administratif. Tipe ini ialah pemimpin yang mampu menyelenggarakan tugas-tugas adminitrasi secara efektif. Dengan kepemimpinan administratif diharapkan muncul perkembangan teknis, menejemen modern dan perkembangan sosial.Kedelapan, Tipe Demokratis. Tipe kepemimpinan demokratis berorientasi kepada manusia dan memberikan bimbingan kepada pengikutnya. Tipe ini menekankan pada rasa tanggung jawab dan kerja sama yag baik antar karyawan. Kekuatan organisasi tipe demokratis terletak pada partisipasi aktif dari setiap karyawan (Buchari Alma, 2007).

\section{Sifat-Sifat Kepemimpinan}

Ordway Tead mengemukakan 10 sifat kepemimpinan sebagai berikut. Pertama, Energi Jasmaniah dan Mental, Seorang pemimpin memiliki daya tahan keuletan, kekuasaan yang luas biasa seperti tidak akan pernah habis. Demikian pula semangat, juga motivasi kerja, disiplin, kesabaran, daya tahan batin, kemauan yang luar biasa untuk mengatasi semua permasalan yang dihadapi. Kedua, Kesadaran Akan Tujuan dan Arah, Ia memiliki keyakinan teguh akan kebenaran dan keteguhan dalam mencapai tujuan yang 
terarah. Ketiga, Antusiasme, Dia yakin bahwa tujuan yang hendak dicapai akan memberikan harapan sukses dan membangkitkan semangat optimisme dalam bekerja. Keempat, Keramahan dan Kecintaan, Sifat ramah mempunyai kebaikan dalam mempengaruhi orang lain sehingga menimbulkan kasih sayang, simpati yang tulus, diikuti oleh kesediaan berkorban untuk menggapai kesuksesan perusahaan. Kelima, Integritas, Seorang pemimpin mempunyai perasaan sejiwa dan senasib seperjuangan dengan para karyawannya dalam menjalankan perusahaan. Integritas pribadi dan rumah tangga pemimpin merupakan tauladan yang dapat dicontoh oleh karyawannya.

Keenam, Penguasaan Teknis, Agar pemimpi mempunyai wibawa terhadap bawahan maka dia harus menguasai sesuatu pengetahuan atau keterampilan teknis. Ketujuh, Ketegasan Dalam Mengambil Keputusan, Dia harus memiliki kecerdasan dalam megambil keputusan sehingga dia mampu menyakinkan bawahan, dan mendukung kebijakan yang telah diambil dalam pelaksanaan. Kedelapan, Kecerdasan, Seorang pemimpin harus mampu melihat dan memahami sebab dan akibat dari suatu gejala, sepeti menemukan jalan keluar dan mengatasi kesulitan dengan cara yang efektif. Kesembilan, Keterampilan Mengajar (Teaching Skill), Seorang pemimpin atau wirausaha adalah seorang guru yang mampu mendidik, mengarahkan, memotivasi karyawannya untuk berbuat sesuatu yang menguntungkan perusahaan. Dia harus mengatur pelatihanpelatihan, mengawasi pekerjan rutin sehari-hari dan mengevaluasi pekerjaan-pekerjaan karyawan. Kesepuluh, Kepercayaan (Faith) Jika seorang pemimpin disenangi oleh bawahannya makan akan muncul kepecayaan dari bawahan terhadap pemimpin. Kepercayaan bawahan ini akan memunculkan sikap rela berjuang, melaksanakan semua perintah, displin dalam bekerja untuk menjalankan roda perusahaan (Buchari Alma, 2007).

Dalam hal memberikan perintah, maka seorang pemimpin harus menyampaikan perintah secara jelas baik dalam bentuk lisan maupun tertulis. Perintah dalam bentuk tertulis adaah lebih baik jika perintah itu ditujukan untuk banyak orang. Perintah yang samar-samar akan membingungkan orang yang diberi perintah. Ada baiknya dibuatkan papan pengumuman atau tempelan-tempelan di tempat-tempat terlihat dengan jelas oleh karyawan itu. 


\section{Etos Kerja Islami}

Etos berasal dari bahasa yunani yang artinya ethos, yang artinya ciri, sifat atau kebiasaan, adat istiadat atau kecendrungan moral, pandangan hidup yang dimiliki seseorang, suatu kelompok orang atau suatu bangsa. dalam Hand Book Of Psychology Term, etos diartikan sebagai pandangan khas suatu kelompok sosial, sistem nilai melatar belakangi adat istiadat dan tata cara suatu komonitas (Ahmad Janan Asifudin, 2004).

Etos berasal dari bahasa Yunani (ethos) yang memberikan arti sikap, kepribadian, watak, karakter, serta keyakinan atas sesuatu. Sikap ini tidak saja dimiliki oleh individu, tetapi juga oleh kelompok bahkan masyarakat. Etos di bentuk oleh kebiasaan, pengaruh budaya, serta sistem nilai yang diyakininya. Dari kata etos ini, dikenal pula kata etika, etiket yang hampir mendekati pada pengertian akhlak atau nilai-nilai yang berkaitan dengan baik buruk (moral) sehingga dalam etos tersebut terkandung gairah atau semangat yang kuat untuk mengerjakan sesuatu secara optimal, lebih baik, dan bahkan berupaya untuk mencapai kualitas kerja yang sesempuna mungkin (Toto Tasmara, 2002).

Sedangkan kerja secara bahasa (etimologi) adalah melakukan sesuatu. Sedangkan secara istilah (termenologi) adalah suatu aktifitas yang mendorong setiap manusia untuk mewujudkan sesuatu sehingga bisa menumbuhkan sebuah tanggung jawab dan rasa ingin berkarya demi terciptanya hal yang diinginkan (Ahmad Janan Asifudin, 2004). Tidak semua aktivitas manusia dapat dikategorikan sebagai bentuk pekerjaan karena didalam makna pekerjaan terkandung dua aspek yang harus dipenuhinnya secara nalar, yaitu aktivitas yang dilakukan dan apa yang dilakukan. Etos kerja, menurut Mochtar Buchori dapat diartikan sebagai sikap dan pandangan terhadap kerja, kebiasaan kerja, ciri-ciri atau sifat-sifat mengenai cara kerja yang dimiliki seseorang, suatu kelompok manusia atau suatu bangsa (Ahmad Janan Asifudin, 2004).

Sedangkan etos kerja islami semangat untuk menapaki jalan lurus. Didalam hal mengambil keputusan pun, para pemimpin pemegang amanah, termasuk para hakim, harus berlandaskan pada etos jalan lurus tersebut, sebagaimana Daud a.s sewaktu ia diminta untuk memutuskan perkara yang adil dan harus didasarkan pada nilai-nilai kebenaran (Toto Tasmara, 2002).

\section{Karakteristik Etos Kerja Islami}


Manusia adalah mahluk bekerja, dengan bekerja manusia menyatakan eksistensi dirinya dalam kehidupan masyarakat. Bekerja pada umumnya merupakan fundamental bagi manusia dan karenanya menjadi hakikat kodrat yang selalu terbawa dalam setiap jenjang perkembangan kemanusiaannya. Bekerja sebagai pernyataan eksistensi diri manusia sebagai pengalaman kesatuan diri, yang melibatkan seua unsur yang membentuk kekuatan yaitu jiwa, semangat, pikiran maupun tenaga serta anggota tubuh fisik. Oleh Karena itu eksistensi kehidupan manusia dapat diukur dari pola hidupnya (Musa Asy'ari, 1997). Etos kerja islami mempunyai beberapa karakteristik meliputi Al-Shalah, Il-Itqan, Al-Ihsan, Al-Mujahadah, Tanafus dan mencermati nilai waktu. Adapun karakteristik etos kerja islami dapat dijelaskan sebgai berikut (Didin Hafifuddin dan Heri Tanjung, 2003) Pertama, Al-Shalah (Baik, bermanfaat dan compatbible).

Ada dua syarat mutlak suatu pekerjaan dapat digolongkan sebagai amal shaleh yaitu lahir dari keikhlasan niat pelaku dan pekerjaan itu memiliki nilai-nilai kebaikan berdasarkan kriteria yang ditetapkan oleh syara', sunnah nabi dan akal sehat. Islam hanya memerintahkan atau menganjurkan pekerjaan yang baik dan bermanfaat bagi kemanusiaan, agar setiap pekerjaan mampu member nilai tambah dan mengangkat derajat manusia baik secara individual maupun kelompok.

Kedua, Al-Itqan (Kemantapan dan kesempurnaan).

Kualitas kerja yang Il-Itqan yaitu hasil pekerjaan yang dapat mencapai standar idel pekerjaan secara teknis. Untuk itu diperlukan dukungan pengetahuan dan skill yang optimal. Islam menganjurkan ummatnya agar terus menambah dan mengembangkan ilmunya dan tetap berlatih. Konsep Il-Itqan memberikan penilaian lebih dari hasil pekerjaan.

Ketiga, Al-Ikhsan (Melakukan yang terbaik dan lebih baik lagi).

Kualitas Ikhsan mempunyai dua makna dan dua pesan yaitu pertama, melakukan yang terbaik dari yang dapat dilakukan. Dengan makna ini pengertiannya sama dengan itqan. Pesan yang dikandungnya antara lain agar setiap muslim memiliki komitmen terhadap dirinya untuk berbuat yang lebih baik dalam segala hal yang ia kerjakan, apabila untuk kepentingan umat. Kedua, memiliki makna yang lebih baik dari kualitas pekerjaan sebelumnya. Makna ini memberikan pesan peningkatan kinerja yang terus menerus, seiring dengan bertambahnya pengetahuan, pengalaman, waktu, dan sumber daya lainnya. Hal ini juga untuk peningkatan kualitas dan kuantitas dakwah. 
Setiap pekerjaan yang dilandasi niat baik dan keikhlasan dalam melaksanakan seseorang pada kesungguhan hati dalam melakukan bidang pekerjaannya agar menghasilkan yang terbaik. Hal ini akan menjauhkan diri seseorang dari rasa dengki, iri, tamak, rakus, serakah dan sebagainya.

Keempat, Al-Mujahadah (Kerja keras dan optimal)

Mujahadah adalah makna yang luas seperti yang didefinisikan oleh ulama' yakni mengarahkan segenap daya dan kemampuan yang ada dalam merealisasikan setiap pekerjaan yang baik, sebab, sesungguhnya Allah SWT telah menyediakan fasilitas segala sumber daya yang diperlukan yaitu menundukkna seluruh isi langit dan bumi untuk manusia. Tinggal bagaimana manusia sendiri dalam mendayagunakannya secara optimal guna mendapatkan ridha Allah.

\section{Faktor-Faktor Yang Mempengaruhi Etos Kerja Islami}

Beberapa faktor yang mempengaruhi etos kerja islami, diantaranya adalah: Agama, Budaya, Sosial Politik, Kondisi lingkungan, Pendidikan, Motivasi Intrinsik individual (Toto Tasmara, 2002).

\section{METODE PENELITIAN}

Metode penelitian pada dasarnya merupakan cara ilmiah untuk mendapatkan data dengan tujuan dan kegunaan tertentu. Dalam melaksanakan sebuah penelitian, metode merupakan salah satu hal penting. Dengan menggunakan suatu metode maka penelitian yang dilakukan akan lebih mudah dilakukan oleh seorang peneliti. Penelitian yang dilakukan akan mendapatkan hasil penelitian dengan mudah dan cepat. Penelitian ini bersifat lapangan yang dilakukan di PT. Disthi Mutiara Suci. Banyubiri Kecamatan Muncar Kabupaten Banyuwangi. Penelitian lapangan (Field Research) dapat juga dianggap sebagai pendekatan luas dalam penelitian kualitatif atau sebagai metode untuk mengumpulkan data kualitatif (Lexy J. Moleong, 2012). Metode penelitian kualitatif ini sering disebut penelitian naturalistik karena penelitiannya dilakukan pada kondisi yang alamiah (natural setting) (Asifuddin dan Beni A Saebani, 2012).

Secara umum, sumber data yang diperoleh oleh peneliti dalam penelitian ini terdiri dari dua macam, yaitu: Pertama, Sumber data Primer adalah sumber data yang langsung memberikan data kepada pengumpul data. Sehingga dengan demikian yang menjadi sumber data primer disini adalah wawancara langsung kepada pimpinan PT. Disthi Mutiara Suci Banyuwangi. Kedua, Sumber data Sekunder adalah sumber data tidak 
secara langsung memberikan data pada pengumpul data. Sehingga data sekunder ini dapat berupa buku, artikel, jurnal, majalah atau data dari internet yang berkaitan dengan penelitian yang dilakukan.

Untuk menghasilkan data yang sempurna maka peneliti menggunakan teknik pengumpulan data. Teknik pengumpulan data merupakan langkah yang paling strategis dalam penelitian, karena tujuan utama dari penelitian adalah mendapatkan data (Sugiono, 2018). Dalam masalah penelitian ini, peneliti melakukan pengumpulan data dengan beberapa metode, diantaranya:

Pertama, Observasi

Observasi adalah pengamatan dan pencatatan secara sitematis terhadap fenomenafenomena yang diteliti. Memang konsep observasi berasal dari bahasa latin yang berarti melihat dan memperlihatkan, kemudian observasi diarahkan pada kegiatan memperhatikan secara akurat, mencatat fenomena yang muncul, terutama dalam disiplin ilmu, baik ilmu eksakta maupun ilmu-ilmu sosial. Dengan demikian peneliti harus berpedoman kepada desain penelitian.

Kedua, Dokumentasi

Dokumentasi adalah teknik mencari data mengenai segala yang berupa catatan, transkip, buku, surat kabar, majalah, agenda dan lainnya. Metode ini memiliki tingkat kebenaran yang lebih tinggi, karena kejadian suatu proses dapat terungkap secara imperis dan selanjutnya dapat dijadikan sebagai bukti yang sangat kuat.

Ketiga, Wawancara

Wawancara adalah tehnik pengumpulan data melalui pengamatan dengan melakukan tanya jawab secara lisan. Metode ini digunakan dengan cara wawancara terbuka untuk memperoleh data yang akurat dan optimal. Data yang dilaporkan harusalah deskriptif dan menyajikan pemaknaan data tersebut. Kegiatan ini dilakukan kepada pihak-pihak terkait untuk mendapat data yang dibutuhkan (Nawawi, 2014).

Setelah data yang diperlukan oleh peneliti terkumpul, maka peneliti akan mengelola data yang didapat dalam suatu metode tertentu agar data tersebut lebih proporsional dan representatif. Dalam penelitian kualitatif, data diperoleh dari berbagai sumber, dengan menggunakan teknik pengumpulan data yang bermacam-macam (triangulasi), dan dilakukan secara terus-menerus sampai datanya jenuh.

\section{HASIL DAN PEMBAHASAN}




\section{Implementasi Manajemen Kepemimpinan Dalam Meningkatkan Etos Kerja Islami Karyawan Pasca Pailit Di PT. Disthi Mutiara Suci}

Pada praktiknya, manajemen yang digunakan di PT. Disthi Mutiara Suci adalah manajemen kepemimpian dengan dilandaskan sistem kekeluargaan dengan tidak membuang sikap hormat antara bawahan ke atasan. Hal itu terlihat ketika PT. Disthi Mutiara Suci mengalami pailit, pimpinan di perusahaan tersebut membuat keputusan untuk mengurangi karyawan sehingga terjadilah PHK dengan tidak meninggalkan tanggungjawab yaitu memberikan hak untuk karyawan yaitu pesangon sesuai ketentuan ketenagakerjaan yang berlaku. Dengan kata lain manajemen yang di terapkan di PT. Dithi Mutiara Suci adalah model manajemen kepemimpinan partisipatif dimana itu berarti manajemen kepemimpinan yang memberikan kesempatan kepada bawahannya untuk secara aktif baik mental, spiritual, fisik, maupun material dalam kiprah di organisasi. Sebagaimana yang telah di aplikasikan di lapangan bahwa perusahaan tersebut menerapkan bagaimana tidak hanya atasannya yang aktif namun juga bawahannya.

Dalam perjalanannya PT Dishti Mutiara Suci menerapkan tipe manajemen kepemimpinan populistis dimana pemimpin ini mampu menjadi pemimpin rakyat, berpegang teguh pada nilai masyarakat, pesamaan dengan faktanya yang ada di lapangan adalah seorang pemimpin yang ada PT. Disthi Mutiara suci adalah tipe pemimpin yang populistis terbukti bahwa pemimpin tersebut mengayomi karyawannya dengan cara pemimpin tersebut tidak terlalu mengekang karyawannya dan pemimpin tersebut bagaimana bisa menyelami sikap karyawannya sehingga lebih mengetahui apa yang karyawan tersebut inginkan dan juga pemimpin di perusahaan ini tetap berpengang kepada aturan yang di tetapkan di perusahaan. Tidak hanya tipe populistis yang ada pada diri pemimpin PT. Disthi Mutiara Suci ini namun juga tipe administratif dan juga tipe demokratis dimana tipe administratif adalah seorang pemimpin mampu menyelenggarakan tugas-tugas adminitrasi secara efektif. Dengan kepemimpinan administratif diharapkan muncul perkembangan teknis, menejemen modern dan perkembangan sosial. Faktanya bahwa pemimpin PT. Disthi Mutiara Suci merupaka tipe yang adminitrasi dikarenakan manajemen yang diterapkan di peusahaan tersebut menggunakan manajemen modern dan mengikuti perkembangan teknologi. Hal ini sangan menguntungkan bagi perusahaan karena di zaman yang milenial ini kita tidak 
luput dengan teknologi dengan adanya teknologi, suatu bisnis akan lebih mudah dan ringan dalam melakukan aktifitasnya.

Sedangkan untuk tipe demokratis merupakan tipe kepemimpinan demokratis, berorientasi kepada manusia dan memberikan bimbingan kepada pengikutnya. Tipe ini menekankan pada rasa tanggung jawab dan kerja sama yang baik antar karyawan. Sedangkan menurut faktanya bahwa kepemimpinan yang diterapkan di perusahaan merupaka tipe demokratis juga, mengapa demikian karena menurut hasil penelitian bahwa pimpinan tersebut merupakan pemimpin yang tidak hanya mengandalakan pendapat sendiri dalam mengambil sebuah keputusan, sehingga memerlukan pendapat karyawannya juga namun memang ada beberapa keputusan yang tidak melibatkan karyawan dan hanya bagian pimpinan saja. Hal itu sangatlah wajar dan juga pimpinan tersebut memberikan arahan kepada karyawanya agar selalu memiliki tanggung jawab yang besar terhadap pekerjaannya sehingga apa yang dikerjakan akan maksimal dan antara pemimpin dan karyawannya memiliki hubungan baik sehingga menciptakan kerja sama yang baik dan menguntungkan terhadap kelancaran perusahaan.

Namun dari teori dalam buku Buchari Alma tidak semuanya di aplikasikan di dalam meningkatkan etos kerja islami karyawan di PT. Disthi Mutiara Suci. Adapun tipe yang tidak di miliki oleh seorang pimpinan PT. Disthi Mutiara Suci adalah Tipe Kharismatis, Paternalistis dan Maternalistis, Militeristis, dan Otokratis. Namun hal itu tidak mengurangi kekuatan seorang pimpinan untuk memimpin suatu perusahaan yang besar ini. Dan juga tipe yang tidak dimiliki pimpinan PT. Disthi Mutiara Suci ini tidak berpengaruh karna menurut peneliti sikap Populistis, Administratif dan Administratif sudah cukup untuk meningkatkan etos kerja karyawan pasca pailit di PT. Disthi Mutiara Suci.

Sedangkan teori yang diungkapkan pada buku yang dikarang oleh Ahmad Ibrahim Abu Sinn terkait dengan kewajiban seorang pemimpin kepada karyawannya sudah dilakuan oleh pimpinan PT. Disthi Mutiara Suci untuk meningkatkan etos kerja islami karyawan pasca pailit seperti mengajak karyawannya untuk menjalankan tugas dengan amanah, memiliki kepercayaan terhadap kemampuan bawahan dan mendelegasikan beberapa wewenang, menunjukkan suri tauladan yang baik atas semua aktivitas yang dilakukan dan terkahir melakukan pengawasan dan audit terhadap kinerja karyawan secara amanah, namun disini menurut penelitian point terakhir ini tidak dilakukan secara 
maksimal karena susahnya trasportasi ke lokasi perusahaan sehingga terkadang pimpinan memantau yang dimana seharusnya setiap minggu, namun dilakukan terkadang dua minggu satu kali atau bahkan sebulan sekali, tetapi pimpinan terus memantau lewat telephone sehingga pimpinan mengetahui apa saja yang di lakukan karyawannya.

Faktor penghambat dan pendukung dalam meningkatkan etos kerja islami karyawan pasca pailit PT. Disthi Mutiara Suci.

\section{Faktor pendukung}

Yang menjadi faktor pendukung manajemen kepemimpinan dalam meningkatkan etos kerja Islami karyawan pasca pailit di PT. Disthi Mutiara Suci ini diantaranya adalah pemberian jabatan yang laya kepada karyawan yang sudah bekerja dengan baik dan juga agar bisa di tiru oleh karyawan yang lain, pelatihan-pelatihan, komunikasi yang baik antara pimpinan ke bawahannya, bawahan ke bawahan dan antara pimpinan satu dengan yang lain karna seyogyanya suatu komunikasi itu sangatlah penting dalam keberlangsungan suatu bisnis, pemberian masa libur yang cukup lama dengan tidak memotong gaji. Berikut pembahasan lebih jelasnya.

Pertama, Promosi jabatan

Promosi jabatan tentunya sering dilakukan di beberapa perusahaan dan mayoritas perusahaan menerapkan promosi jabatan. PT. Disthi Mutiara Suci juga menerapkan hal serupa, karena dirasa sangat diperlukan, dengan adanya promosi jabatan karyawan jadi lebih semangat bekerja dan lebih giat dengan di janjikan oleh jabatan yang tinggi dan tentunya gaji yang tinggi pula. Hal itu juga merupakan salah satu faktor pendukung dalam meningkatkan etos kerja karyawan pasca pailid. Menurut data yang didapat bahwa karyawan yang telah ada sejak lama atau yang bertahan dari perusahaan pailid sampai dengan saat ini sudah melakukan kenaikan jabatan yang lebih tinggi, karena perusahaan merasa berterima kasih kepada karyawan yang tetap setia dalam keadaan sulit sampai saat ini.

Menurut peneliti promosi jabatan merupakan hal yang menjadikan karyawan lebih semangat bekerja walaupun dengan di janjikan sesuatu berupa promosi jabatan dan lainnya dan strategi itu cukup memberikan dampak terhadap pemingkatan etos kerja karyawan.

Kedua, Pelatihan 
Memiliki karyawan yang ahli dibidangnya merupakan asset perusahaan dan keuntungan bagi karyawan, hal itu tentunya didukung dengan adanya pelatihan-pelatihan. PT. Disthi Mutiara Suci menerapkan pelatihan bagi security, yang pada tahun-tahun sebelumnya tidak dilaksanakan karena pada saat ini pemimpin menginginkan yang terbaik bagi karyawannya. Menurut data yang peneliti dapat model pelatihannya adalah pelatihan security karena karyawan yang bekerja di sana mayoritas bagian keamanan. Dengan adanya pelatihan tentunya memberikan rasa percaya diri dan semangat bekerja bagi karyawan sehingga menjadikan perusahaan semakin baik dan berkembang,

Ketiga, Komunikasi

komunikasi yang baik sangantlah penting, antara atasan kepada bawahan dan yang lebih utama adalah antara karyawan dan pimpinan itu mempunyai tujuan yang sama sehingga lebih mempermudah terciptanya suatu etos kerja islami karyawan pasca pailit yang baik. Karna menurut data yang didapat bahwa pimpinan PT. Disthi Mutiara Suci sangat menerapkan komunikasi yang baik dengan begitu tumbuh rasa kekeluargaan. Hal ini sangan dibutuhkan karena jika antara pemimpin dan karyawan tidak bersatu atau tidak akur akan menyebabkan ketimpakangan disuatu perusahaan. Komunikasi ini juga merupakan faktor pendukung meningkatnya etos kerja karyawan dengan arahan pemimpin tentunya akan memberikan perkembangan yang segnifikan terhadap perusahaan.

Keempat, Pemberian masa libur karyawan

Pemberian masa libur karyawan yang cukup panjang cukup berdampak positif kepada karyawan, sehingga hal ini juga merupakan salah satu faktor pendukung terhadap peningkatan etos kerja karyawan. Sistem pemberian libur karyawan yaitu 2 minggu libur dan 2 minggu bekerja, dengan alasan Karena lokasi yang cukup jauh dan tidak memungkinkan untuk selalu pulang pergi lokasi. Dan menurut data yang didapat bahwa pemberian waktu libur yang serupa sangatlah efektif karena dengan begitu uga karyawan lebih focus kepada pekerjaan di lokasi karena sudah cukup lama diberi libur dan berkupul bersama keluarga, karena beberapa keluhan karyawan sering kali masalah keluarga. Pemberian waktu libur sebelum pailid yang diterapkan di PT. Disthi Mutiara Suci adalah 3 minggu kerja dan 1 minggu libur. Menurut peneliti pemerapan libur bagi karyawan merupakan hal yang baik dan cukup meningkatkan etos kerja karyawan dengan begitu karyawan libih seangat bekerja dan tidak memikirkan hal lainnya. 


\section{Faktor penghambat.}

Setiap usaha tentunya ada yang pro dan ada juga yang kontra di sini faktor penghambat dari penerapan manajemen kepemimpinan dalam meningkatkan etos kerja islami karyawan pasca pailit adalah penghalang dari faktor pendukung itu sendiri yaitu

Pertama, Karyawan yang terkadang sulit diberi tahu, sehingga menyebabkan sulitnya terbentuk etos kerja islami karyawan yang mengakibatkan kemerosotan terhadap perusahaan, hal itu sangat disanyangkan karena dengan begitu sulit menciptakan lingkungan yang kondusif di perusahaan. Menururt data yang didapat bahwa pimpinan memberikan sanksi kepada karyawan yang tidak mematuhi perintah-perintah atau aturanaturan yang ada pada perusahaan namun tentunya semakin banyak karyawan tentunya semakin banyak pula kepala atau pemikinan yang harus disatukan dan hal itu tidak mudak namun peneliti menyimpulkan bahwa karyawan yang sulit untuk diberi tahu wajib diberi teguran dan sanksi yang layak karna untuk mencapai suatu tujuan besar juga memerlukan pemikiran yang sama.

Kedua, Karyawan yang tidak memprioritaskan profesionalisme dalam bekerja, hal ini terjadi akibat karyawan yang tidak bisa memilah masalah pribadi dan perusahaan yang nantinya akan berdampak kepada perusahaan, karena menurut penelitian bahwa karyawan yang tidak profesional memberikan dampak negatif terhadap keberlangsungan persahaan, namun disini pimpinan tidak tinggal diam dalam menyikapi hal tersebut sehingga pimpinan memberikan beberapa tahapan untuk karyawan yang bermasalah adalah: Memberikan teguran terhadap karyawannya agar tidak terulang kembali, Memberikan SP (Surat Peringatan) kepada karyawan, Mencabut status karyawannya apa bila karyawan masih saja melakukan kesalahan yang serupa. Dengan adanyan sanksi yang diterapkan tentunya karyawan akan berfikir ulang untuk tidak tidak professional karna aka nada

Ketiga, Kurang kesetiaan karyawan terhadap perusahaan. PT. Disthi Mutiara Suci merupakan perusahaan yang bergerak dibidang budidaya kerang laut mutiara yang penjualannya sampai manca negara dan tentunya perusahaan ini merupakan perusahaan yang besar dengan jumlah laba yang cukup besar pula, tidak menutut kemungkian segala macam kejahatan terjadi didalamnya, menurut penelitian bahwa tindakan kejahatan ada yang bersumber dari dalam perusahaan dengan memberikan informasi penting. Hal itu 
yang paling sangat disayangkan terhadap karyawan yang tidak setia terhadap perusahan dan hal itu perusahaan memberikan sanksi yang adil.

Keempat, Sulitnya trasportasi menuju lokasi PT. Disthi Mutiara Suci di teluk Banyubiru. Hal ini merupakan faktor yang menjadi penghambat karena lokasi yang cukup sulit, PT. Disthi Mutiara Suci berlokasi pada teluk Banyu biru yang perjalannya harus menggunakan kendaraan laut atau kapal laut dan kapal laut yang di miliki oleh perusahaan hanya satu dan sedangkan kapal tersebut berfungsi untuk membawa logistik dan keperuan lainnya, karyawan atau pimpinan yang harus pergi ke lokasi sering kali ikut kapal nelayan yang akan mencari ikan ke daerah sekitar teluk Banyu biru tersebut atau jika karyawan. Faktor ini menjadi penghambat terhadap meningkatnya etos kerja islami karyawan karena sulitnya transportasi yang sehingga karyawan kurang disiplin.

\section{KESIMPULAN}

Implementasi manajemen kepemimpinan dalam meningkatkan etos kerja Islami karyawan pasca Pailit di PT. Disthi Mutiara Suci, telah sesuai dengan apa yang menjadi aturan yang berlaku. Tipe kepimimpinan yang menjadi tolak ukur meningkatnya etos kerja Islami karyawan telah beberapa terpenuhi seperti Tipe Populistis dimana pemimpin yang populistis terbukti bahwa pemimpin tersebut mengayomi karyawannya dengan cara pemimpin tersebut tidak terlalu mengekang karyawannya dan pemimpin tersebut bagaimana bisa menyelami sikap karyawannya sehingga lebih mengetahui apa yang karyawan tersebut inginkan, pemimpin administratif manajemen yang diterapkan di peusahaan tersebut menggunakan manajemen modern dan mengikuti perkembangan teknologi dan pemimpin yang demokratis dimana tidak hanya mengandalakan pendapat sendiri dalam mengambil sebuah keputusan.

Faktor pendukung yang mempengaruhi meningkatnya etos kerja karyawan adalah promosi jabatan yang diterapkan di perusahanaan, pelatihan bagi karyawan, komunikasi

yang baik antara atasan ke bawahan, pemberian masa libur yang cukup untuk para karyawan dan pimpinan memiliki kepercayaan yang baik terhadap karyawannya dan juga melakukan pengawasan terhadap kinerja karyawan.

Faktor penghambat yang mempengaruhi meningkatnya etos kerja karyawan adalah karyawan yang kurang profesionalisme dalam bekerja, kurang kesetiaan karyawan terhadap perusahaan dan sulitnya trasportasi menuju lokasi PT. Disthi Mutiara Suci sehingga sulitnya karyawan maupun pimpinan menuju lokasi perusahaan. 


\section{DAFTAR PUSTAKA}

Abdul Rivai dan Darsono Prawironegoro. (2015). Manajemen Strategis. Jakarta: Mitra Wacana Media.

Ahmad Janan Asifudin. (2004). Etos Kerja Islami. Surakarta: Muhammadiyah University Press.

Ahmad Jarifin. (2019). Strategi Bisnis Ala Rasulullah yang Tak Pernah Rugi. Yogyakarta: Araska.

Asifuddin dan Beni A Saebani. (2012). Metodologi Penelitian Kualitatif. Bandung: CV. Pustaka Setia.

Asifuddin dan Beni A Saebani. (2012). Metodologi Penelitian Kualitatif. Bandung: CV Pustaka Setia.

Buchari Alma. (2007). Kewirausahaan. Bandung: Alfabeta.

Didin Hafifuddin dan Heri Tanjung. (2003). Manajemen Syari'ah Dalam Praktik. Jakarta: Gema Insanin.

Hadari Nawawi. (1993). Kepemimpinan Menurut Islam. Yogyakarta: Gadjah Mada University Press.

Hendri Safri. (2017). Manajemen dan Organisasi dalm Pandangan Islam. Jurnal Of Education Management, 156.

Hendyat Soetopo. (1992). Pengantar Operasional Administrasi. Surabaya: Usaha Nasional.

Irham Fahmi. (2018). Pengantar Ilmu Kepemimpinan. Depok: PT. Rajagrafindo Persada. Irhami Fahmi. (2018). Pengantar Ilmu Kepemimpinan. Depok: PT. Raja Grafindo Persada.

John Supriyanto. (2014). Manajemen. Yogyakarta: Gadjah Mada University Press.

Lexy J. Moleong. (2012). Metode Penelitian Kualitatif. Bandung: CV. Pustaka Setia. M. Manullang. (2008). Pengantar Bisnis. Yokyakarta: Gadjah Mada University Perss. Marsyaf Rinaldi. (Oktober 2016). Pengaruh Disiplin Kerja dan Etos Kerja Serta Gaya Kepemimpinan Situasional Terhadap Kinerja Pegawai di Kantor Badan Penanggulanan Bencana Daerah Kota Palu. e Jurnal Katalog Vol 4 NO 1 , 161162. 
Muhammad Syafi'i Antonio. (2007). Muhammad SAW The Super Leader Super Manager. Jakarta: Tazkia Multimedia.

Musa Asy'ari. (1997). Etos Kerja dan Pemberdayaan Ekonomi Umat. Yogyakarta: Lesfi.

Nana Herdiana Abdurrahman. (2013). Manajemen Bisnis Syari'ah \& Kewirausahaan. Bandung: CV Pustaka Setia.

Nanda Hidayan dkk. (2017). Etos Kerja Islam Sebagai Upaya Meningkatkan Kinerja. Prosiding Nasional dan Call Paper Ekonomi dan Bisnis. Jember: Snaper-Ebis.

Nawawi. (2014). Metodologi Penelitian Hukum Islam. Malang: Genius Media.

Onong Uchjana Efendi. (2009). Human Relation \& Public Relation. Bandung : CV Mandar Maju.

Sadili Samsudin. (2006). Manajemen Sumber Daya Manusia. Bandung: Pustaka Setia.

Soetopo Hendyat. (1992). Pengantar Operasional Administrasi. Surabaya: Usaha Nasional.

Sugiono. (2018). Metode Penelitian Kuantitatif dan R\&D. Bandung: Alfabeta.

Syafi'i Antonio. (2007). Muhammad SAW The Super Leader Super Manager. Jakarta: Tazkia Multimedia.

T. Hani Handoko. (2015). Manajemen. Yogyakarta: BPFE-Yogyakarta.

Toto Tasmara. (2002). Membudidayakan Etos Kerja Islam. Jakarta: Gema Insani Perss.

Veitzal Rivai Zainal dkk. (2017). Kepemimpinan dan Perilaku Organisasi. Jakarta: PT. Raja Grafindo Persada. 